\title{
Intracranial internal carotid aneurysm causing diplopia
}

Brian T Kloss ${ }^{1 *}$, Rahul Patel ${ }^{2}$ and Anne Marie Sullivan ${ }^{3}$

\section{Abstract}

Internal carotid intracranial aneurysms are a relatively rare form of intracranial aneurysm that presents with diplopia, retro-orbital pain and unilateral headaches. The symptoms are progressive and the diagnosis should be considered in a patient presenting with these complaints. Underlying hypertension and advanced age are specific risk factors.

\section{Case Report}

A 73-year-old diabetic male presented with progressively worsening diplopia and difficulty reading for 2 months. He denied having any fever, trauma, headache, numbness or weakness of his extremities or changes in other senses. Vital signs, physical and neurological exams were unremarkable, except for diplopia on right lateral gaze with distance, but not on left lateral gaze. CT, CTA, and MRI of the brain were obtained in addition to a cerebral angiogram (Figures 1, 2, 3, 4 and 5).

Internal carotid aneurysms located in the intracavernous region account for $3-5 \%$ of all intracranial aneurysms [1]. Systemic hypertension is a primary risk factor for development of aneurysm. Life-threatening risk or permanent neurological complications of most carotid cavernous aneurysms (CAA) are relatively low [2]. Despite this, ophthalmic morbidity is a leading consideration for treatment [3]. Diplopia (65\% of cases), retroorbital pain, and unilateral headache are the most common symptoms at presentation of CAA, followed by $\mathrm{CN}$ III and CN VI paresis [4]. The mainstay of symptomatic CAA has moved away from surgical and endovascular balloon techniques in favor of endovascular stenting and coiling approaches [4].

\section{Consent}

Patient consent was obtained and the case report qualified for IRB exemption given the lack of specific identifiable patient information within the case report and clinical images.

\footnotetext{
* Correspondence: Klossb@upstate.edu

'SUNY Upstate Medical University, Department of Emergency Medicine, NY, USA

Full list of author information is available at the end of the article
}

Author details

'SUNY Upstate Medical University, Department of Emergency Medicine, NY, USA ${ }^{2}$ SUNY Upstate Medical University, NY, USA ${ }^{3}$ SUNY Upstate Medical University, Department of Radiology, NY, USA

\section{Authors' contributions}

BK oversaw the editorial aspects of the article and wrote the case presentation. RP wrote the section of disease presentation and

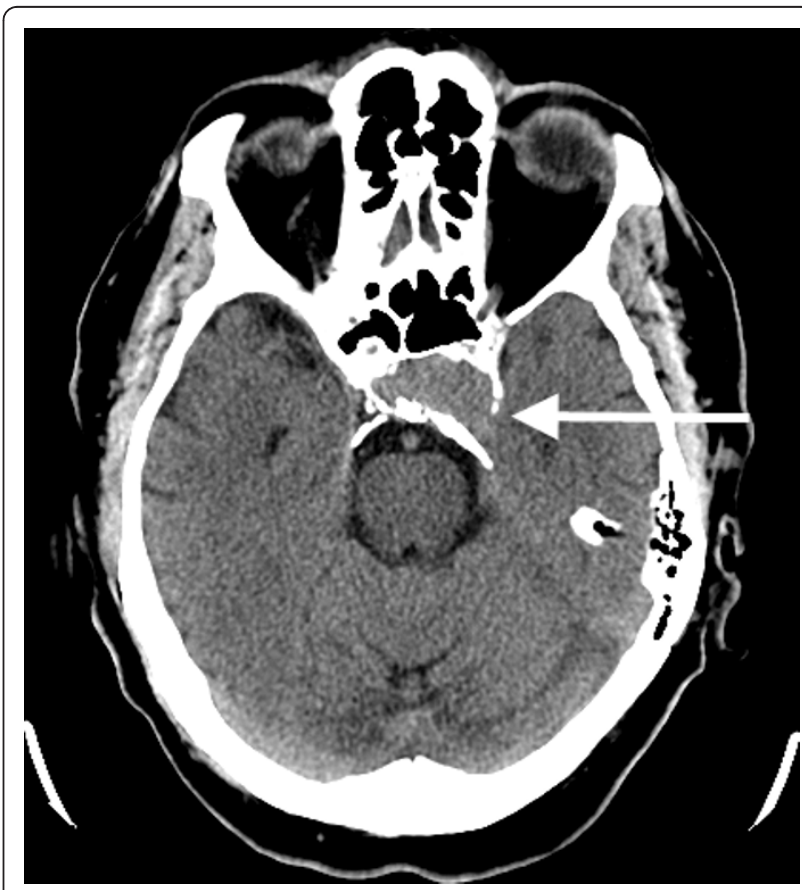

Figure $1 \mathrm{CT}$ without contrast demonstrates a soft tissue attenuation mass filling the sella with adjacent bone remodeling (arrow). 


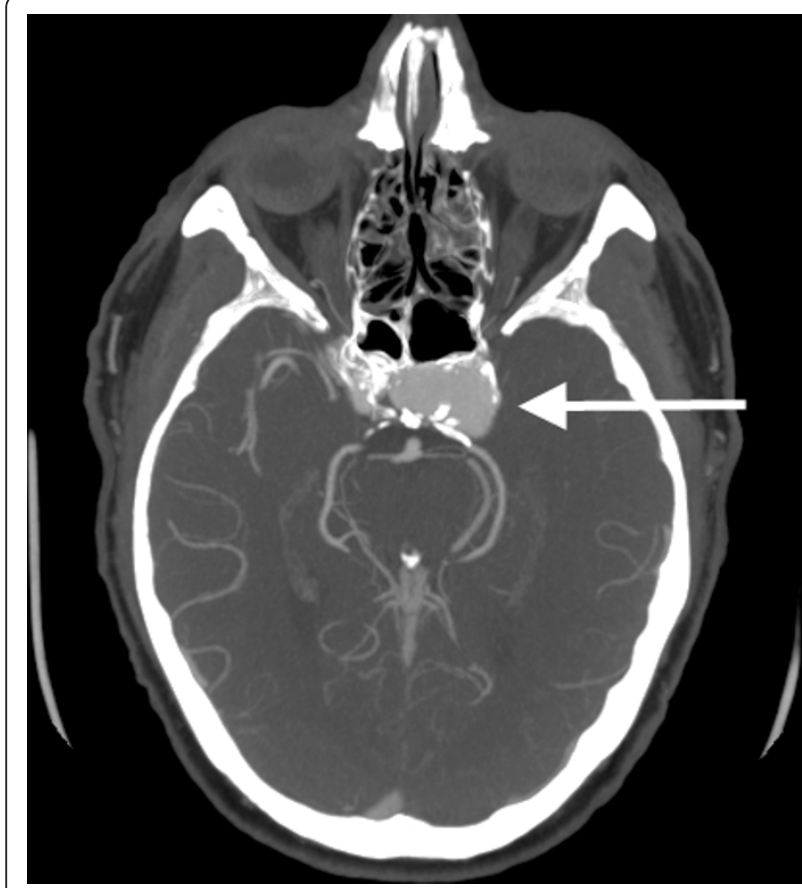

Figure 2 On the post contrast images, there is a $1.8 \times 2.9 \times$ $1.6 \mathrm{~cm}$ (AP $\times$ transverse $\times$ craniocaudad) aneurysm with incomplete wall calcification originating from cavernous portion of the left internal carotid artery.

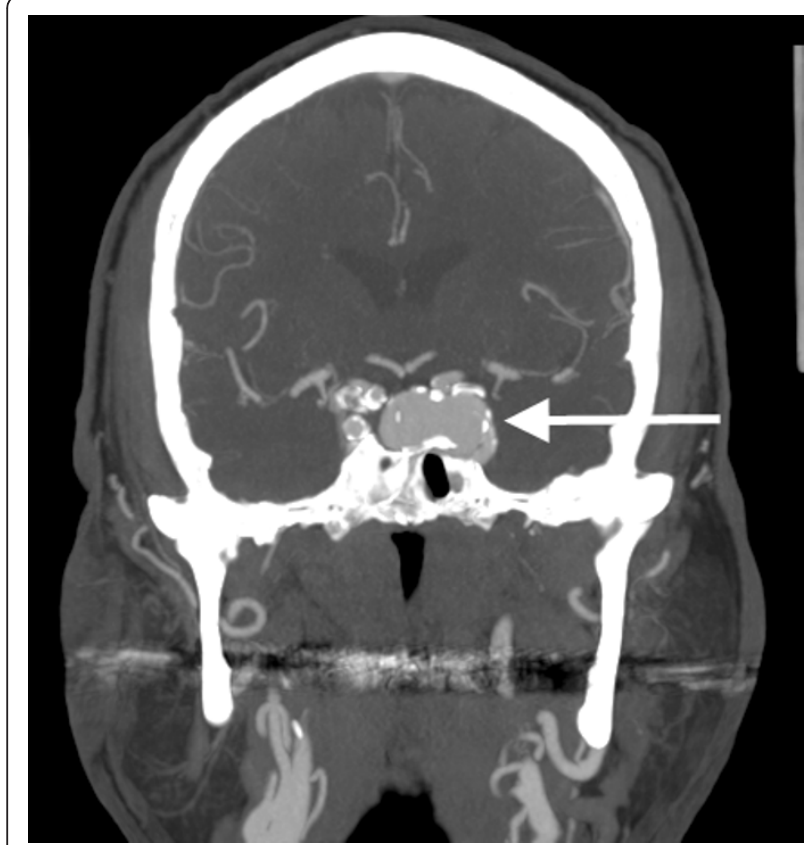

Figure 3 On the post contrast images, there is a $1.8 \times 2.9 \times$ $1.6 \mathrm{~cm}$ (AP $\times$ transverse $\times$ craniocaudad) aneurysm with incomplete wall calcification originating from cavernous portion of the left internal carotid artery.

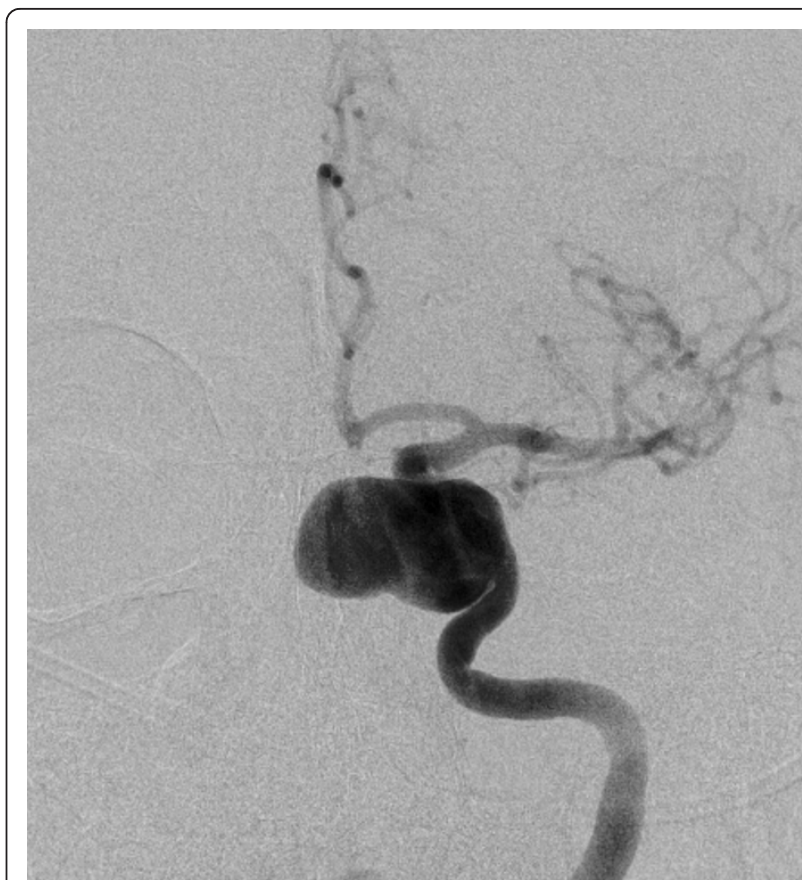

Figure 4 Findings are confirmed by cerebral angiography and colorized

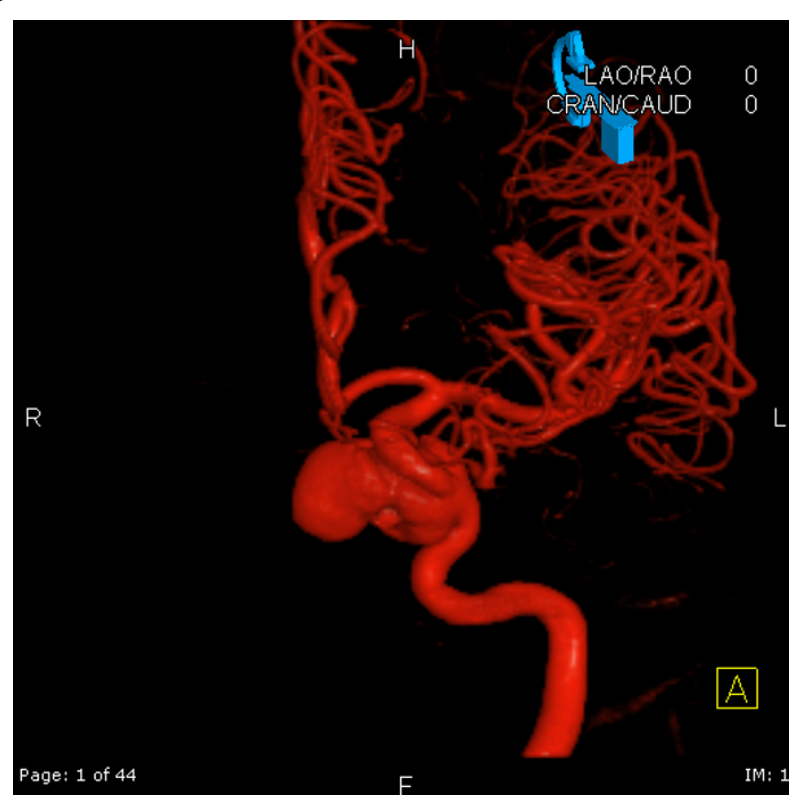

Figure 5 Findings are confirmed by cerebral angiography and colorized.

management. AS reviewed and edited the clinical images. All authors read and approved the final manuscript.

\section{Competing interests}

The authors declare that they have no competing interests. 
Received: 13 December 2010 Accepted: 2 September 2011

Published: 2 September 2011

\section{References}

1. Bars HW, Blackwood W, Meadows SP: Intracavernous carotid aneurysms. A clinical-pathological report. Brain 1971, 94:607-622.

2. Kupersmith MJ, Hurst R, Berenstein A, Choi IS, Jafar J, Ransohoff J: The benign course of cavernous carotid artery aneurysms. J Neurosurg 1992, 77:690-693.

3. Johnston SC, Wilson CB, Halbach W, Higashida RT, Dowd CF,

McDermott MW, Applebury CB, Farley TL, Gress DR: Endovascular and surgical treatment of unruptured cerebral aneurysms: Comparison of risks. Ann Neurol 2000, 48:11-19.

4. Stiebel-Kalish H, Kalish Y, Bar-On RH, Setton A, Niimi Y, Berenstein A, Kupersmith MJ: Presentation, natural history, and management of carotid cavernous aneurysms. Neurosurgery 2005, 57(5):850-7, discussion 850-7.

doi:10.1186/1865-1380-4-56

Cite this article as: Kloss et al: Intracranial internal carotid aneurysm causing diplopia. International Journal of Emergency Medicine 2011 4:56.

\section{Submit your manuscript to a SpringerOpen ${ }^{\circ}$ journal and benefit from:}

- Convenient online submission

- Rigorous peer review

- Immediate publication on acceptance

- Open access: articles freely available online

- High visibility within the field

- Retaining the copyright to your article

Submit your next manuscript at $\gg$ springeropen.com 